\title{
A COMPARISON OF ORTHOPAEDIC TRAUMA CASES OPERATED ON DURING THE COVID-19 PANDEMIC WITH DIFFERENT PERIODS: A SINGLE CENTRE STUDY
}

\author{
Akalın Yavuz, Ulusaloglu Can Armagan, Avci Ozgur, Cevik Nazan, \\ Guler Olcay Burak, Ozturk Alpaslan \\ Health Sciences University, Bursa Yuksek Ihtisas Research and Training Hospital \\ Department of Orthopedics and Traumatology, Yıldırım, Bursa, Turkey
}

Primljen/Received 23. 11. 2020. god.

Abstract: Introduction: To compare orthopaedic trauma cases treated surgically in our clinic during the COVID-19 pandemic in Turkey with surgically-treated trauma cases in previous periods, and to discuss these in the light of literature.

Materials and Methods: Patient data of 3 different periods were compared. Group 1 included cases in the time period March 11 - May 30, when the hospital was operating as a pandemic hospital for the COVID-19 pandemic in Turkey. Group 2 included cases from the equivalent time period the year before the pandemic, thought to have similar patient characteristics, and Group 3 covered the time period immediately before 11 March when COVID-19 was known in the world but there had not been any cases diagnosed in Turkey. Operations performed in our clinic because of orthopaedic trauma counts 186 patients in Group 1, 262 patients in Group 2, and 261 patients in Group 3.

Results: A decrease of $29 \%$ was observed in trauma cases during the pandemic. In Group 1,62 of 186 patients were aged $>65$ years, and 43 of these $(69 \%)$ had a hip fracture, in Group 2,33 (58\%) patients aged $>65$ years underwent surgery for hip fracture, and in Group 3,60 (75\%) patients. The time from hospital admission to surgery was mean $3.76 \pm 3.55$ days in Group 1, $3.18 \pm 3.08$ days in Group 2, and $2.68 \pm 2.33$ days in Group $3(p=0.017)$. The number of cases of attempted suicides was $6,3,3$, respectively in the three groups $(\mathrm{p}=0.184)$. 30-day mortality was determined in 5,3 , and 4 cases, respectively $(\mathrm{p}=0.460)$.

Conclusions: A decrease in the number of trauma cases was observed during the pandemic. However, there was no such decrease in hip fractures in elderly patients despite the quarantine of those aged
Prihvaćen/Accepted 22. 01. 2021. god.

$>65$ years. The workforce of the clinic was divided up during the pandemic for the diagnosis and follow-up of COVID-19 cases and thus there was no reduction in the workload of orthopedists as trauma surgery continued at the rate of $71 \%$. Therefore, strict regulations must be applied which will decrease the risk of the spread of infection, and implement a multidisciplinary workflow for a more rapid discharge of trauma patients.

Keywords: Covid-19 pandemic, trauma, hip fracture, quarantine.

\section{INTRODUCTION}

The new coronavirus, first seen in China's Hubei province in December 2019, causes a disease progressing with severe acute respiratory failure (SARSCoV-2), and was named corona virus disease 2019 (COVID-19) $(1,2)$. COVID-19 is spread by droplets and with symptoms such as fever, cough, dyspnea, and fatigue, which causes an upper respiratory tract disease similar to influenza. However, just as some patients may exhibit these symptoms, asymptomatic patients may also be seen. Cases of COVID-19 increased rapidly throughout the world, and on March 11, 2020, the World Health Organisation declared COVID-19 a pandemic. By March 11, 119.239 cases and 4287 deaths had been recorded in 115 countries (3).

Examining recent pandemics, the Spanish flu in the 20th century infected 50 million people, and the H1N1 outbreak in 2009 was the first pandemic of the 21 st century $(4,5)$. After COVID-19 was first identified in China, in December 2019, it spread throughout the world rapidly and became a pandemic. Many 
countries started to take different precautions, including social isolation, curfews, and regional quarantine (6). COVID-19 is known to cause greater morbidity and mortality in the elderly and those who are immune-compromised (7-11). In Turkey, the first COVID-19 case was diagnosed on March 10. The first precaution taken by the Turkish Ministry of Health on March 11 was to impose a partial curfew for citizens over 65 and under the age of 20, age groups known to be more severely affected by the disease.

As our hospital is a training and research centre, when COVID-19 cases started to be found, elective surgeries planned for March 17 - May 30 were postponed in accordance with the Ministry of Health instructions. During that period, the only operations performed were for spinal, pelvis, and upper and lower extremity trauma. In addition, throughout the pandemic, orthopaedic specialists and residents worked in wards with patients diagnosed with COVID-19 and in the COVID-19 emergency wards, as did all the physicians in the hospital.

Several guidelines have been published which show variations related to patients requiring surgery during the pandemic (12-15). The variability is caused by the continuously changing flow of information about the disease, and differences in health care infrastructures and demographic data in different countries. The aim of this study was to examine cases of orthopaedic trauma which had undergone surgery in our clinic during the COVID-19 pandemic in Turkey while curfew was in place and to compare and discuss these cases with those of previous periods.

\section{MATERIAL AND METHODS}

Approval for this study was granted by the Ministry of Health and the Local Ethics Committee (2011-KAEK-25 2020/06-19). The data for this retrospective study were retrieved from the hospital and clinic archives. The data which had been collected prospectively were compared retrospectively between the period of the pandemic and two previous cross-sectional periods. This research adhered to the principles of the Declaration of Helsinki.

Group 1 was formed from the time period March 11 - May 30, when the hospital was operating as a pandemic hospital. Group 2, in the same period from the year before the pandemic, and Group 3 covered an equivalent time period immediately before March 11 when COVID-19 was known in the world but there had not been any cases diagnosed in Turkey.

In Groups 2 and 3, elective cases and emergency operations, other than for trauma, were excluded. As the curfew implemented during the pandemic included individuals aged $<20$ years and $>65$ years, the patients in the 3 study groups were separated into subgroups of $<20$ years, $20-64$ years, and $>65$ years. The groups were compared in respect of whether the trauma was low-energy or high-energy, the injured body region, time from trauma to surgery, and postoperative length of stay in hospital.

The daily working of the Orthopaedics and Traumatology Clinic changed during the COVID-19 pandemic, where basic changes were made because of the precautions taken. In addition to the general precautions instructed by the Ministry of Health, our hospital was designated as a pandemic hospital, so the A-block building was assigned for COVID-19 patients, and all the surgical clinics located in that block were transferred to another building.

In this period, all patients were treated using the necessary personal protective equipment (PPE), and no problems were experienced with PPE. All patients presenting at the Emergency Department were questioned and evaluated in respect of COVID-19 symptoms of fever, fatigue, respiratory problems, cough, nasal discharge, metallic taste in the mouth, loss of sense of smell, gastroenteritis, and flu-like symptoms. Patients with physical examination findings, a suspicious history, and low oxygen saturation were evaluated with pulmonary tomography and blood tests grouped as a COVID-19 panel, also nasopharyngeal swabs were taken for RT-PCR test.

Patients with suspected COVID-19 for whom surgery was planned were first admitted to the suspected cases ward and evaluations were made in respect of COVID-19. When the hospital bed capacity allowed, patients were isolated in single rooms. Special care was taken to isolate patients aged $>65$ years as they were known to be affected more severely by COVID-19. Efforts were made to reduce the risk of infection spread by implementing the necessary measures aimed at reducing preoperative waiting time and accelerating discharge.

\section{Statistical Analysis}

Data obtained in the study were analysed statistically using SPSS for Windows vn. 15.0 software. Descriptive statistics were reported as number and percentage for categorical variables and as mean \pm standard deviation (SD), minimum and maximum values for numerical variables. Rates in the groups were compared using the Chi-squared test. Multiple group comparisons of two of the numerical variables were made with the Kruskal-Wallis test, and the Mann-Whitney U-test was applied to subgroup analyses. A value of $p$ $<0.05$ was accepted as statistically significant. 


\section{RESULTS}

Operations were performed in our clinic on 186 patients for orthopaedic trauma in Group 1, 262 patients in Group 2, and 261 patients in Group 3. The demographic data of the groups are shown in Table 1.

In Group 1, the 186 patients comprised 106 $(56.9 \%)$ males and $80(43.1 \%)$ females with a mean age of 45.2 years (range, 2-94 years); $46(24.7 \%)$ in the $\leq 20$ years age group, $78(41.9 \%)$ in the $20-64$ years age group and $62(33.3 \%)$ in the $\geq 65$ years age group. Operations were performed because of trauma on the upper extremity of $64(34.4 \%)$ patients, on the lower extremity of $116(62.4 \%)$, and on both upper and lower extremities of $6(3.2 \%)$.

In Group 2, the 262 patients comprised 141 $(53.8 \%)$ males and $121(46.1 \%)$ females with a mean age of 47.1 years (range, 1-91 years); $84(32.1 \%)$ in the $\leq 20$ years age group, $122(46.6 \%)$ in the $20-64$ years age group and $56(21.4 \%)$ in the $\geq 65$ years age group. Operations were performed because of trauma on the upper extremity of $113(43.1 \%)$ patients, on the lower extremity of $142(54.2 \%)$, and on both upper and lower extremities of $7(2.7 \%)$.

In Group 3, the 261 patients comprised 138 (52.8\%) males and $123(47.1 \%)$ females with a mean age of 46.1 years (range, 1-93 years); 65 (24.9\%) in the $\leq 20$ years age group, $116(44.4 \%)$ in the $20-64$ years age group and $80(30.7 \%)$ in the $\geq 65$ years age group. Operations were performed because of trauma on the upper extremity of $106(40.6 \%)$ patients, on the lower extremity of $147(56.3 \%)$, and on both upper and lower extremities of $8(3.1 \%)$.

Examining the age distributions of the patients, a statistically significant difference was determined in Group 2, with the lowest number of patients in the $>$ 65 years age group $(56 / 262,21.4 \%)$, and the most in the $\leq 20$ years age group $(84 / 262,32.1 \%)(p=0.035)$.

All the patients associated with 30-day mortality in all the groups were patients aged $>65$ years with hip fracture. In Group 1, 5 patients, in Group 2, 3 patients, and in Group 3, 4 patients, died within 30 days. No significant difference was determined between the groups in respect of 30-day mortality $(\mathrm{p}=0.460)$.

The cases were separated as low-energy and high-energy trauma. Fractures occurred as a result of high-energy trauma in 41/186 (22\%) patients in Group 1, in 45/262 (17.2\%) in Group 2, and in 44/261 $(16.8 \%)$ in Group 3. No statistically significant difference was determined between the groups $(p=0.307)$.

When the mechanism of trauma was examined, no difference was determined between the groups in respect of the rate of traffic accidents $(p=0.890)$. A statistically significant difference was determined between the groups in respect of the numbers of falls from heights $(p=0.007)$. In the subgroup analyses, a statistically significant difference was determined between Group 1 and Group 2, and between Group 1 and Group $3(\mathrm{p}=0.010)$.

The time from hospital admission to surgery was mean $3.76 \pm 3.55$ days in Group 1, $3.18 \pm 3.08$ days in

Table 1. Demographic data and general information of the patients in the groups

\begin{tabular}{|c|c|c|c|c|}
\hline \multirow{2}{*}{\multicolumn{2}{|c|}{ Total Patients (n) }} & \multirow{3}{*}{$\begin{array}{c}\text { Group 1 } \\
186 \\
106(56.9 \%)\end{array}$} & \multirow{3}{*}{$\begin{array}{c}\text { Group 2 } \\
262 \\
141(53.9 \%)\end{array}$} & \multirow{3}{*}{$\begin{array}{c}\text { Group 3 } \\
261 \\
138(52.8 \%) \\
\end{array}$} \\
\hline & & & & \\
\hline \multirow{2}{*}{$\begin{array}{c}\text { Sex } \\
(\mathrm{n}, \%)\end{array}$} & Male & & & \\
\hline & Female & $80(43.1 \%)$ & $121(46.1 \%)$ & $123(47.2 \%)$ \\
\hline \multirow{3}{*}{$\begin{array}{c}\text { Trauma Localization } \\
\text { (n, \%) }\end{array}$} & Lower extremite & $116(62.4 \%)$ & $142(54.2 \%)$ & $147(56.3 \%)$ \\
\hline & Upper extremite & $64(34.4 \%)$ & $113(43.1 \%)$ & $106(40.6 \%)$ \\
\hline & Lower + Upper & $6(3.2 \%)$ & $7(2.7 \%)$ & $8(3.1 \%)$ \\
\hline \multirow{3}{*}{$\begin{array}{c}\text { Age } \\
(\text { years }) \\
(\mathbf{n}, \%)\end{array}$} & $\leq \mathbf{2 0}$ & $46(24.7 \%)$ & $84(32.1 \%)$ & $65(24.9 \%)$ \\
\hline & 21-64 & $78(41.9 \%)$ & $122(46.6 \%)$ & $116(44.4 \%)$ \\
\hline & $\geq 65$ & $62(33.3 \%)$ & $56(21.1 \%)$ & $80(30.7 \%)$ \\
\hline \multicolumn{2}{|c|}{$\begin{array}{c}\text { Time to surgery } \\
(\text { day }),(\text { Mean } \pm \text { SD) }\end{array}$} & $3.76 \pm 3.55$ & $3.18 \pm 3.08$ & $2.68 \pm 2.33$ \\
\hline \multicolumn{2}{|c|}{$\begin{array}{l}\text { Post-surgery hospital stay } \\
\text { (day), (Mean } \pm \text { SD) }\end{array}$} & $2.83( \pm 3.17)$ & $2.78( \pm 4.11)$ & $2.81( \pm 3.90)$ \\
\hline \multicolumn{2}{|c|}{ 30-day mortality rate (n, \%) } & $5(2.7 \%)$ & $3(1.1 \%)$ & $4(1.5 \%)$ \\
\hline \multirow{2}{*}{$\begin{array}{c}\text { Trauma energy } \\
(\mathbf{n}, \%)\end{array}$} & High energy & $41(22 \%)$ & $45(17.2 \%)$ & $44(16.8 \%)$ \\
\hline & Low energy & $145(78 \%)$ & $217(82.8 \%)$ & $218(83.2 \%)$ \\
\hline
\end{tabular}




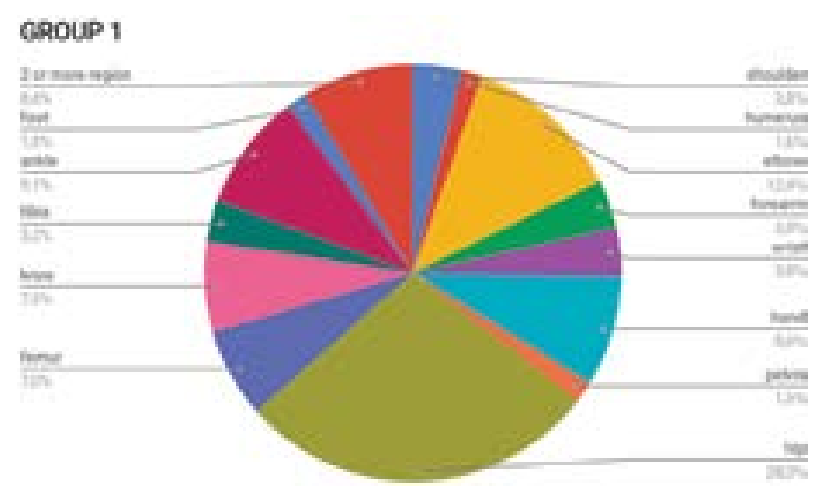

Figure 1. Fracture localisation of the patients in Group 1

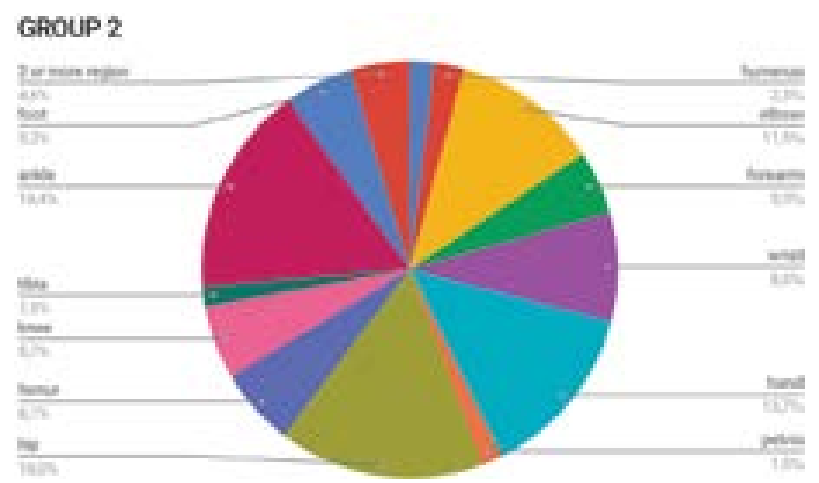

Figure 2. Fracture localisation of the patients in Group 2

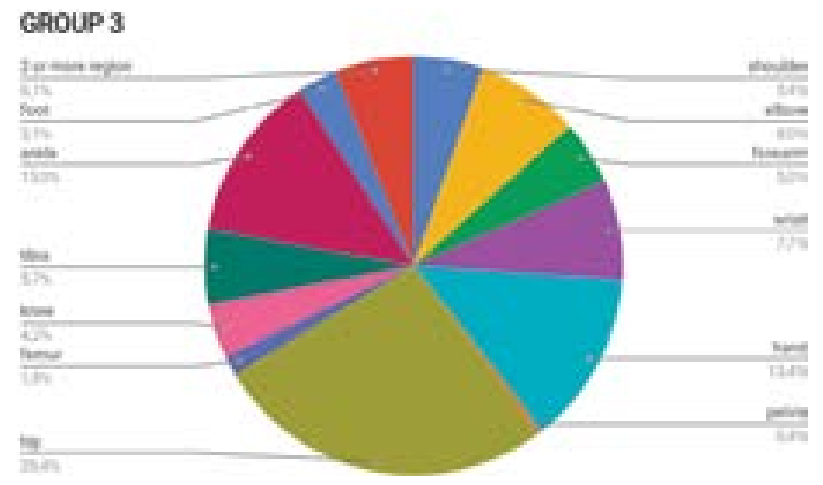

Figure 3. Fracture localisation of the patients in Group 3

Group 2, and $2.68 \pm 2.33$ days in Group $3(\mathrm{p}=0.017)$. The length of postoperative stay in hospital was mean $2.83 \pm 3.17$ days in Group 1, $2.78 \pm 4.11$ days in Group 2 , and $2.81 \pm 3.90$ days in Group $3(\mathrm{p}=0.293)$. The preoperative time in the hospital was determined to be statistically significantly longer in Group 1 than in Group $3(\mathrm{p}=0.004)$.

The patients aged $>65$ years were compared in respect of the region of the traumatic fracture, and hip fractures were determined in 43/62 (69.4\%) patients in Group 1, in 33/56 (58.9\%) in Group 2, and in 60/80 $(75 \%)$ in Group 3. No statistically significant difference was determined between the groups in respect of the rates of hip fractures in patients aged $>65$ years ( $p$ $=0.137$ ).

The distribution of the fracture localisation in the groups is shown in Figures 1-3. The number of cases of attempted suicide was 6 in Group 1, 3 in Group 2, and 3 in Group 3, with no statistically significant difference determined between the groups $(p=0.184)$.

\section{DISCUSSION}

The process of quarantine applied during the COVID-19 pandemic, which affected the whole world, was only applied as continuous quarantine to the $<20$ years age group and the $>65$ years age group in Turkey. In the later periods, with the aim of mobilisation, permission was granted to these individuals to go outside within walking distance of their home in specific time periods. At weekends and on official holidays, all age groups throughout the country were put into lockdown. The main aim of this study was to examine the effects of the COVID-19 pandemic and the quarantine on the distribution of orthopaedic trauma cases requiring surgery and the treatment processes and to discuss the pandemic in the light of literature from an orthopaedic perspective.

In comparison with the previous periods, a decrease in the number of trauma cases during the pandemics was recorded. However, despite this decrease, no difference was seen in the number of hip fractures in the elderly, which can occur as a result of trauma, such as a simple fall in the home. When the total trauma cases in the groups were examined, the vast majority were seen to be fractures in the hip region. This can be explained by the fact that hip fractures, especially in the elderly can be the result of minor trauma such as a simple fall at home. The number of cases of attempted suicide was seen to be 6,3 , and 3 in Groups, 1,2 , and 3, respectively. Although not to a statistically significant level, the number of attempted suicides was greater during the pandemic than in the other periods, which could be attributed to the activation of psychiatric disorders with the concerns of the pandemic and the quarantine process.

A study in Belgium reported a $32 \%$ decrease in trauma cases during the COVID-19 pandemic (16). In the current study, a total of 186 patients underwent surgery because of trauma during the pandemic, compared to 262 in Group 2, and 261 in Group 3. Thus a decrease of approximately $29 \%$ was determined in orthopaedic trauma cases during the pandemic and quarantine. When the reduction in cases was examined according to age groups, it was seen to be greater in the 20-64 years age group who were not included in the continuous quarantine. Although this seems to be con- 
tradictory, it is thought that there was a reduced risk of workplace accidents during the pandemic because of flexible working hours and fewer people in the workplace. The reduction in orthopaedic trauma cases aged $<20$ years is thought to be due to the restrictions on games and sports activities after school and at weekends. Furthermore, with the recommendation of the National Orthopaedics Association, cases where there was an option of conservative and surgical treatment, the conservative method should be applied to reduce the risk of COVID-19 infection spread, and this has also contributed to the decrease.

Of the 186 patients operated on in our clinic because of trauma during the pandemic, 62 were aged $>65$ years, and of these $43(69 \%)$ had a hip fracture. This rate of hip fracture in patients aged $>65$ years was similar in Group 2 (n : 33,58\%) and in Group 3 (n : 60,75\%). No difference was determined between the groups in respect of patients aged $>65$ years with a hip fracture. In a multi-centre study in Wuhan, China, it was reported that $58.3 \%$ of the fractures during the pandemic were hip fractures (17). In another single centre study in Belgium, it was reported that $23(28 \%)$ of 80 trauma cases operated on during the pandemic were hip fractures in elderly patients (16). For reasons such as social distancing and restrictions on others entering the home if not necessary, there was thought to be an increase in jobs within the home undertaken by elderly individuals living alone, and therefore in future similar outbreaks or pandemics, the provision of social support is very important. There should also be more information and education given to the elderly about protective measures to be taken in these periods, such as sufficient lighting inside the house, sitting to take a bath, the use of non-slip shoes and slippers, and the techniques of slowly and carefully standing from a lying position.

In a multi-centre study in Spain during the pandemic, which evaluated mortality rates in hip fractures, it was reported that mortality developed in the follow-up period in 5 (4\%) of 124 patients who were treated surgically and in $8(66 \%)$ of 12 patients treated conservatively. In the same study, the mortality rate of COVID-19 patients was reported to be $7 / 23$ (30.4\%) (18). Another multi-centre study in New York reported 30 -day mortality in $17 / 138(12.3 \%)$ hip fracture patients (115 Covid negative, 17 Covid positive, 14 with suspected Covid), and the mortality rate for hip fractures in the previous year was 3/115 (3\%) (19). Following surgery to hip fractures in elderly COVID-19 positive patients during the pandemic in Italy, Catellani et al. (20) reported 7-day mortality in 4 of 13 patients.

It can be understood from these studies that the mortality rate was increased because of the systemic effects created in patients with a weaker immune system such as the elderly with a hip fracture and a diagnosis of COVID-19. In contrast, in a study in Spain during the pandemic, the frequency of hip fractures and mortality rates were seen to be no different from those of previous periods (18). In the current study, 5 patients operated on because of hip fracture in the $>$ 65 years age group in Group 1 during the pandemic, 3 patients in Group 2, and 4 patients in Group 3, were lost to 30-day mortality. According to these data, the frequency of hip fractures and mortality rates were similar in all three groups. Differences in the mortality rates in similar studies can be attributed to several reasons such as comorbidities.

That there was no increase in the mortality rates in the current study could also be associated with there not being COVID-19 positive patients as the test results of 9 suspected COVID patients were negative. In the study by Catellani et al. (20), although the mortality rate was high after surgery in COVID-19 positive patients, it was recommended that surgical treatment was applied early to these fractures during the pandemic for reasons such as patient mobilisation, the provision of physiological ventilation, and comfort in bed. We also believe that early surgery and early rehabilitation in COVID-19 positive or suspected patients was beneficial for the COVID-19 treatment, and therefore, surgery should be performed in the early period with the provision of the necessary protective equipment against the risk of COVID-19 infection spread.

Hospitals are high-risk areas in respect of infection spread during the pandemic. Moreover, the disease is known to be more severe in the elderly with higher morbidity and mortality rates $(1,7,9,11)$. Therefore, it is important that the preoperative preparation, treatment, and follow-up procedures are completed in as short a time as possible for all trauma patients, and especially for the elderly. In our clinic, it was aimed to reduce the length of stay in hospital to a minimal level for trauma patients during the pandemic. However, because of the potential requirement for intensive care, elective operations were postponed and the number of operating rooms was reduced. Accordingly, taking the existing precautions into consideration, there was only one operating room where it was possible to operate on orthopaedic trauma patients. In addition, there was a loss of manpower as orthopaedists were seconded to other clinics to deal with COVID-19 patients. The time from hospital admission to surgery was mean $3.76 \pm$ 3.55 days in Group 1, $3.18 \pm 3.08$ days in Group 2, and $2.68 \pm 2.33$ days in Group 3, and thus it can be seen that there was no reduction in preoperative waiting time.

The preoperative waiting time of patients with 30day mortality was seen to be mean $7.4 \pm 1.81$ (range, 
5-10) days in Group 1, 3.66 \pm 1.52 (2-5) days in Group 2 , and $2.78 \pm 1.70$ (1-5) days in Group 3. The reason for the longer stay in hospital before surgery in Group 1 can be considered to be associated with prolonged evaluations because of the suspicion of COVID-19 positivity in 4 of the 5 patients who died. Vijay Kumar Jain et al. (21) reviewed COVID-19-positive trauma cases and recommended that especially because of proximal femur fractures and the presence of comorbidities in the elderly, early surgery in advanced centres with an intensive care unit would be more appropriate for the improvement of respiratory functions in this age group of patients.

Therefore, rather than postponing early surgery of fractures in patients aged $>65$ years because of the suspicion of COVID-19, the implementation of conditions so that early surgery can be performed with the provision of the necessary PPE is of great importance in reducing morbidity and mortality. The physiological ventilation provided by early surgery and rehabilitation will be useful in improving the pulmonary functions affected by the COVID-19 virus. In addition, when planning internal and external hospital assignments in possible future outbreaks, it was seen that despite flexible working arrangements and quarantine, the workload of orthopaedic trauma cases during the pandemic continued in a course near to that of normal periods. Therefore, operating room conditions should be planned and organised accordingly. In this way, the preoperative waiting time can be reduced with arrangements to be made, and by increasing patient circulation, the risk of infection spread within the hospital can be reduced, and working conditions can be made easier.

There were some limitations to this study, primarily the retrospective design. Another limitation could be said to be that the 30-day follow-up was short for the examination of mortality, and comorbid diseases and the treatments applied were not compared. However, as the information records system of the patients is kept well there was no loss of data, and the fact that this was a single-centre study, unlike the majority of studies that have compared trauma cases during the COVID-19 pandemic, can be considered strong aspects of the study.

\section{CONCLUSION}

With the whole world affected by the COVID-19 pandemic, changes in daily life habits have led to many changes in healthcare management, hospital working organisation and the approach to patients, and these changes are continuing. Although the effect of the pandemic has decreased in some countries, as no definitive treatment or vaccine has yet been found, there is an increased risk of virus spread as a second wave, and there are concerns of further restrictions such as quarantine. Just as in examples from around the world, the results of this study showed that although there was a slight decrease in orthopaedic trauma cases, they continued at the rate of $71 \%$ during the pandemic. When it is considered that the priority in dealing with the virus is to reduce the spread of infection, it is important that hospital treatments and discharge of patients are completed in as short a time as possible. Therefore, when planning pandemic interventions, there must be an awareness that the workload of orthopaedic trauma will continue, and a shorter length of stay in hospital will significantly reduce the risk of COVID-19 infection spread.

\section{Acknowledgment}

None.

Conflict of Interests: The authors declare that there are no conflicts of interest related to this article.

Funding: None

\section{Licensing}

This work is licensed under a Creative Commons Attribution 4.0 International (CC BY 4.0) License.

\title{
Sažetak
}

\section{UPOREĐIVANJE SLUČAJEVA ORTOPEDSKE TRAUME OPERISANIH TOKOM PANDEMIJE KOVID-19, SA RAZLIČITIM PERIODIMA: STUDIJA JEDNOG CENTRA}

\author{
Akalın Yavuz, Ulusaloglu Can Armagan, Avci Ozgur, Cevik Nazan, Guler Olcay Burak, Ozturk Alpaslan \\ Health Sciences University, Bursa Yuksek Ihtisas Research and Training Hospital \\ Department of Orthopedics and Traumatology, Yıldırım, Bursa, Turkey
}

Uvod: Uporediti slučajeve ortopedske traume hirurški lečene u našoj klinici tokom pandemije KOVID-19 u Turskoj sa hirurški lečenim slučajevima traume u prethodnim periodima i razmotriti ih kroz literaturu. 
Materijali i metode: Upoređeni su podaci o pacijentima iz 3 različita vremenska perioda. Grupa 1 obuhvatila je slučajeve u vremenskom periodu od 11. marta do 30. maja, kada je bolnica radila kao pandemijska bolnica za vreme pandemije KOVID-19 u Turskoj. Grupa 2 obuhvatala je slučajeve iz ekvivalentnog vremenskog perioda godinu dana pre pandemije, za koje se smatralo da imaju slične karakteristike pacijenta, a grupa 3 pokrivala je vremenski period neposredno pre 11. marta kada je KOVID-19 bio poznat u svetu, ali nije bilo dijagnostikovanih slučajeva u Turskoj. Operacije su rađene u našoj klinici zbog ortopedske traume i to: 186 pacijenata u grupi 1, 262 pacijenta u grupi $2 \mathrm{i}$ 261 pacijentu u grupi 3.

Rezultati: Primećen je pad od $29 \%$ u slučajevima traume tokom pandemije. U grupi 1, 62 od 186 pacijenata bilo je starije od 65 godina, a 43 od njih (69\%) imalo je prelom kuka. U grupi 2, $33(58 \%)$ pacijenta starija od 65 godina operisano je zbog preloma kuka, a u grupi 3, $60(75 \%)$ pacijenata. Vreme od prijema

\section{REFERENCES}

1. Wu F, Zhao S, Yu B, Chen YM, Wang W, Song ZG et al. A new coronavirus associated with human respiratory disease in China. Nature. 2020; 579(7798): 265-9. doi: 10.1038/s41586020-2008-3.

2. Zhou P, Yang X-L, Wang X-G, Hu B, Zhang L, Zhang $\mathrm{W}$ et al. A pneumonia outbreak associated with a new corona virus of probable bat origin. Nature. 2020; 579(7798): 270-3. doi: 10.1038/s41586-020-2012-7.

3. The Lancet Infectious Diseases. COVID-19, a pandemic or not? Lancet Infect Dis. 2020; 20(4): 383. doi: 10.1016/ S1473-3099(20)30180-8.

4. Trilla A, Trilla G, Daer C. The 1918 "Spanish Flu" in Spain. Clin Infect Dis. 2008; 47(5): 668-73. doi: 10.1086/ 590567.

5. Webster RG, Govorkova EA. Continuing challenges in influenza. Ann N Y AcadSci. 2014; 1323(1): 115-39. doi: 10.1111 /nyas. 12462 .

6. Sarac NJ, Sarac BA, Schoenbrunner AR, Janis JE, Harrison RK, Phieffer LS, et al. A review of state guidelines for elective orthopaedic procedures during the COVID-19 Outbreak. J Bone Joint Surg Am. 2020; 102(11): 942-5. doi: 10.2106/JBJS.20.00510.

7. Rothan HA, Byrareddy SN. The epidemiology and pathogenesis of corona virus disease (COVID-19) outbreak. J Autoimmune. 2020; 109: 102433. doi: 10.1016/j. jaut.2020.102433.

8. Guo YR, Cao QD, Hong ZS, Tan YY, Chen SD, Jin HJ, et al. The origin, transmission and clinical therapies on corona virus disease 2019 (COVID-19) outbreak - an update on the status. Mil MedRes. 2020; 7(1): 11. doi: 10.1186/s40779-02000240-0.

9. Liu K, Chen Y, Lin R, Han K. Clinical features of COVID-19 in elderly patients: A comparison with young and middle-aged patients. J Infect. 2020; 80(6): e14-8. doi: 10.1016/j.jinf.2020.03.005. u bolnicu do operacije bilo je prosečno 3,76 $\pm 3,55$ dana u grupi $1,3,18 \pm 3,08$ dana u grupi 2 i 2,68 \pm 2,33 dana u grupi $3(\mathrm{p}=0,017)$. Broj slučajeva pokušaja samoubistava bio je $6,3,3$, u naše tri grupe $(\mathrm{p}=$ 0,184). 30-dnevni mortalitet utvrđen je u 5, 3, odnosno 4 slučaja $(\mathrm{p}=0,460)$.

Zaključak: Tokom pandemije primećen je pad broja slučajeva traume. Međutim, nije došlo do velikog smanjenja preloma kuka kod starijih pacijenata uprkos karantinu starijih od 65 godina. Radna snaga klinike bila je podeljena tokom pandemije na one koji rade na dijagnozi i praćenju slučajeva KOVID-19, i na one koji nisu, tako da nije došlo do smanjenja opterećenja ortopeda, jer je operacija trauma nastavljena po stopi od $71 \%$. Stoga je veomo važno primeniti stroge propise koji će smanjiti rizik od širenja infekcije i primena multidisciplinarnog toka rada za brže otpuštanje pacijenata sa traumom.

Ključne reči: pandemija KOVID-19, trauma, prelom kuka, karantin.

10. Guan WJ, Ni ZY, Hu Y, Liang WH, Ou CQ, He JX, et al. Clinical characteristics of Coronavirus disease 2019 in China. N Engl J Med. 2020; 382(18): 1708-20. doi: 10.1056/ NEJMoa2002032.

11. Zhou F, Yu T, Du R, Fan G, Liu Y, Liu Z, et al. Clinical course and risk factors for mortality of adult patients with COVID-19 in Wuhan, China: a retrospective cohort study. Lancet. 2020; 395(10229): 1054-62. doi: 10.1016/S01406736(20)30566-3.

12. Rodrigues-Pinto R, Sousa R, Oliveira A. Preparing to perform trauma and orthopaedic surgery on patients with COVID-19. J Bone Joint Surg Am. 2020; 102(11): 946-50. doi: 10.2106/JBJS.20.00454.

13. Chang Liang Z, Wang W, Murphy D, Po Hui JH. Novel Coronavirus and orthopaedic surgery: early experiences from Singapore. J Bone Joint Surg Am. 2020; 102(9): 745-749. doi: 10.2106/JBJS.20.00236.

14. Ti LK, Ang LS, Foong TW, Ng BSW. What we do when a COVID-19 patient needs an operation: operating room preparation and guidance. Can J Anaesth. 2020; 67(6): 756-8. doi: 10.1007/s12630-020-01617-4.

15. Ozturk K, Unkar EA, Ozturk AA. Perioperative management recommendations to resume elective orthopaedic surgeries for post-COVID-19 "new normal": Current vision of the Turkish Society of Orthopaedics and Traumatology. Acta Orthop Traumatol Turc. 2020; 54(3): 228-33. doi: 10.5152/j. aott.2020.20183.

16. Hernigou J, Morel X, Callewier A, Bath O, Hernigou P. Staying home during "COVID-19" decreased fractures, but trauma did not quarantine in one hundred and twelve adults and twenty eight children and the "tsunami of recommendations" could not lockdown twelve elective operations. Int Orthop. 2020; 44(8): 1473-80. doi: 10.1007/s00264-020-04619-5.

17. Zhu Y, Chen W, Xin X, Yin Y, Hu J, Lv H, et al. Epidemiologic characteristics of traumatic fractures in elderly patients during the outbreak of coronavirus disease 2019 in China. 
Int Orthop. 2020; 44(8): 1565-70. doi: 10.1007/s00264-02004575-0.

18. Munoz Vives JM, Jornet-Gibert M, Camara-Cabrera J, Esteban PL, Brunet L, Delgado-Flores L, et al. Mortality rates of patients with proximal femoral fracture in a worldwide pandemic: preliminary results of the Spanish HIP-COVID observational study. J Bone Joint Surg Am. 2020;102(13): e69. doi: 10.2106/JBJS.20.00686.

19. Egol KA, Konda SR, Bird ML, Dedhia N, Landes EK, Ranson RA, et al. Increased mortality and major complications in hip fracture care during the COVID-19 pandemic: a New
York city perspective. J Orthop Trauma. 2020; 34(8):395-402. doi: 10.1097/BOT.0000000000001845.

20. Catellani F, Coscione A, D'Ambrosi R, Usai L, Roscitano C, Fiorentino G. Treatment of proximal femoral fragility fractures in patients with COVID-19 during the SARSCoV-2 outbreak in Northern Italy. J Bone Joint Surg Am. 2020; 102(12): e58. doi: 10.2106/JBJS.20.00617.

21. Kumar Jain V, Lal H, Kumar Patralekh M, Vaishya R. Fracture management during COVID-19 pandemic: A systematic review. J Clin Orthop Trauma. 2020; 11 (Suppl 4): S431-41. doi: 10.1016/j.jcot.2020.06.035.

\section{Correspondence to/Autor za korespondenciju}

Alpaslan Ozturk MD

Professor of Orthopaedics and Traumatology

Health Sciences University,

Bursa Yüksek IhtisasResearchand Training Hospital

Department of OrthopedicsandTraumatology,

Yildırım, Bursa, Turkey.

Orcid: 0000-0001-7362-0284

Cell: +905323531031

Fax number: +902242955497

e-mail: ozturkalp16@gmail.com; alpaslan.ozturk@sbu.edu.tr 